\title{
Sciendo
}

\section{THE INFLUENCE OF B2B RELATIONSHIP QUALITY ON OPPORTUNISM AND FIRM PERFORMANCE}

\author{
Amy Chu May YEO ${ }^{1 *}$ \\ Marcus Ee Ken LAl ${ }^{2}$
}

\begin{abstract}
Received: March 2020 | Accepted: November 2020 | Published: December 2020
Please cite this paper as: YEO, A.C.M.:, LAI, M.E.K. (2020) The Influence of B2B Relationship Quality on Opportunism and Firm Performance, Holistica Journal of Business and Public Administration, vol. 11 , iss. 3, pp.59-87
\end{abstract}

\begin{abstract}
The primary objective of the research is to determine the influences of B2B relationship quality and opportunism on firm performance. This study takes a general perspective of business organisations by examining the hypothesised relationships in the context of B2B's in the industrial business environment. The research employs a cross-sectional design whereby quantitative data is collected by means of an online survey. Using non-probability, judgmental and snowball sampling technique, a sample size of 98 employees from the industrial business environment within Malaysia was collected. The gathered data was analysed using statistical software Smart-PLS. The research yields several interesting findings on the association between $B 2 B$ relationship quality and firm performance in the industrial business environment within Malaysia. Findings also unfolded that the quality of a relationship between businesses is able to influence firm performance and opportunism. Opportunism on the other hand was not found to have any influence on Firm Performance. The results of the study implied that the quality of the relationship between businesses that is built upon trust, commitment, satisfaction and information sharing are important in business relationships. A high-quality relationship that is shared among suppliers and customers is able to predict better firm performance and inhibit the negative effect of opportunism.
\end{abstract}

Keywords: B2B Relationship quality; Firm Performance; Opportunism; Trust; Commitment; Satisfaction; Information Sharing

\section{Introduction}

In an industrial business environment context, business relationship can be comprehended as a relationship formed between business organisations (manufacturer - distributor and distributor - customer) which commercial activities takes place (Hayes, 2019). Trade relations are formed when firms reach out to the market to obtain a product

\footnotetext{
1* Corresponding author. Tunku Abdul Rahman University College, Jalan Genting Klang, Setapak, 5330 Kuala Lumpur, Malaysia, yeocm@tarc.edu.my.

2 Sales Manager, Rieckermann Malaysia Sdn Bhd, Malaysia, Marcus_462@hotmail.com.
} 


\section{HOLISTICA Vol 11, Issue 3, 2020, pp.59-87}

or service by transacting with another firm. The quality of the relationship between business-to-business (B2B) in this case is important as the development of relationships equates to an increasing level of business activities (Ford, 1980).

Building on theories of Transaction Cost Economics (TCE) and Social Exchange Theory (SET), it is important to note that firms coexist in the market where socio-economic transactions and outcomes are realized. TCE emphasises on the governance of on-going contractual relations with the assumption of bounded rationality and opportunism (Williamson, 1979) while SET according to Blau (1964, p. ix) seeks to explain "social life in terms of exchange principles by analysing the reciprocal processes composing exchange". The movement of goods or services from a supplier to its customer as a result of trade is not only regulated by the price mechanism (Coase, 1937) but also the good relations that are built upon the exchange between those two (Cropanzano \& Mitchell, 2005) leading to an economic outcome that is inherent for achieving better firm performance.

Meanwhile in a high quality $\mathrm{B} 2 \mathrm{~B}$ relationship, the potential risk of opportunism cannot be undermined. In this respect, formal contractual mechanisms are necessary to safeguard interests of the parties to the exchange (Williamson, 1979). Its ability however to mitigate all forms of opportunism is limited (Lumineau \& Quelin, 2011). Hence, researches are turning to a hybrid approach by including both formal and relational governance mechanisms to curb opportunistic behaviour (Cavusgil, Deligonul \& Zhang, 2004; Huo, Ye \& Zhao, 2015; Huo, Fu, Zhao \& Zhu, 2016). The focus of the research is not on the transactional and economic factors but on the social relations between businesses that is implied to lead to positive economic outcomes (i.e. increase in business activities). Existing studies have explored on the relations between formal contracts (Huo, Ye \& Zhao, 2015), relational norms (Huo et al., 2016), social mechanisms (Ali \& Larimo, 2016) on firm performance and opportunism. However, empirical research on how the quality of B2B relationships that is capable of influencing opportunism and firm performance is still relatively dearth and requires further study.

First, the research theorizes that the B2B relationship quality shared between business organisations as a higher order construct with four dimensions consisting of trust, commitment, satisfaction and information sharing. Second, the influences of B2B relationship quality on opportunism and firm performance will be examined. Finally, the role of opportunism as a potential intervening variable to better explain the effects of B2B relationship quality on firm performance will be uncovered.

SET advocates that there exists a social transaction in an economic relationship (Cropanzano \& Mitchell, 2005). A perfect example of this would be how commitment towards solving a problem of the customer is demonstrated by a service provider when some form of payment is received in exchange for services. From an economic perspective, the price mechanism dictates the choice and movement of goods or services. However, there is an influence of social factors from the exchange relation between firms that cannot be disregarded. The quality of relationships is able to predict better sales 
performances due to reciprocity (Huntley, 2006) and this is evident in the context of Asian countries such as China where relationships are highly valued (Xue, Lu, Shi \& Zheng, 2018).

TCE on the other hand suggests that governance is required to safeguard interests of parties in an exchange due to opportunism and bounded rationality. Opportunism in an exchange is negatively associated with trust, satisfaction, commitment (VázquezCasielles, Iglesias \& Varela-Neira, 2013) and can lead to poor firm performance (Ali \& Larimo, 2016). Some examples of opportunism could be "shirking", whereby one does not perform as per contract specifications (Eisenhardt, 1989) or withholding strategic information (Williamson, 1973). Even when formal contractual mechanisms are utilized to mitigate opportunism risks, it is inadequate to account for all cases due to its incompleteness by reason of bounded rationality (Williamson, 1979). Furthermore, Huo et al. (2015) implied that contracts should not serve as a tool for controlling but rather to establish guidelines and coordinate the functions of both parties.

In times of desperation, it is nothing unusual to organisations necessitating opportunistic actions to their own competitive advantage (Wang \& Yang, 2013) for survival should the conditions prove to be feasible and profitable (John, 1984). As relationship marketing suggests that there is a need to establish, develop and maintain successful relational exchanges (Morgan \& Hunt, 1994), a firm's performance can be built upon the quality of the relationship that is shared with their exchange partners (i.e. manufacturer or suppliers and customers).

Meanwhile, a state of permanence in business relationships or partnerships cannot be generally assumed due to economic uncertainty; as Heraclitus of Ephesus puts forth "change is the only constant" (Kirk, 1951). However, the same does not necessarily apply to businesses because it is cost inefficient to always switch to alternative sources due to the risks and uncertainty that are involved (Ford, 1980). As far as costs are concerned, it is also inefficient for a firm to be organising all forms of transactions on its own (Coase, 1937) because transacting in the market with other firms allow firms to leverage on economies of scale achieved by others. The economic benefits of an exchange hence can only be realized so long as the relationship continues (Williamson, 1979).

These circumstances call for a need to establish a better understanding on how B2B relationship quality can influence firm performance through an increased level of business activities and opportunism that is detrimental to achieving firm performance. In the next section, the research questions pertaining to the problems above will be discussed.

With reference to the issues discussed in the previous section, it is still relatively under researched on how the quality of relationship between businesses is able to predict firm performance and opportunism. Hence, the following research questions are formulated.

- What is the influence of B2B relationship quality on opportunism and firm performance?

- What is the influence of opportunism on firm performance? 
HOLISTICA Vol 11, Issue 3, 2020, pp.59-87

The primary objective of the research in light of the growing importance of business relationships is to determine the influences of B2B relationship quality and opportunism on firm performance. Prior researches in relationship marketing have heavily emphasised on buyer or manufacturer perspectives from a unilateral point of view. The research would take a general perspective of business organisations by examining the hypothesised relationships in the context of B2B.

The following are the objectives of the research:

- To determine the influences of B2B relationship quality on opportunism and firm performance.

- To determine the influences of opportunism on firm performance.

- To find out B2B relationship quality on trust, commitment, satisfaction and information sharing.

\section{Literature Review}

\subsection{Business-to-business (B2B) relationship}

In general, B2B relationships in an industrial environment can exist between manufacturers, distributors and customers. Within the B2B context in an industrial environment, there can be upstream manufacturer of raw materials, downstream processing of the raw materials, packaging organisations, label printing organisations, service organisations, industrial equipment and component suppliers. It can be in the form of supplying goods produced or services by a manufacturer to a customer. In essence, the supply chain of an industrial business environment involves the movement of a manufacturer's product or service to distributors and subsequently to the end consumers in a market (Kenton, 2019).

Figure 1 Supply Chain Network

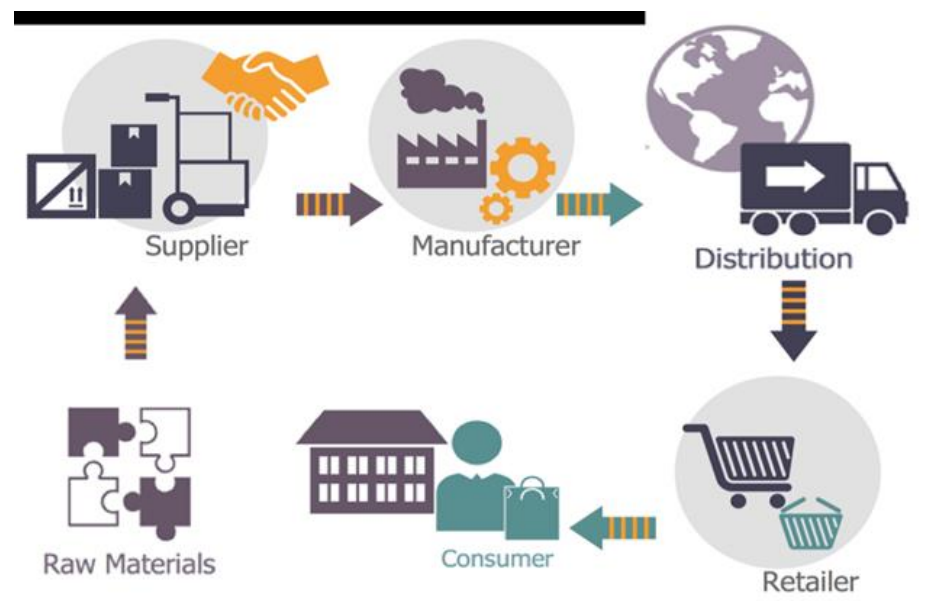

Source: Malik, Kanhere \& Jurdak, 2018 
It is important to develop good business relations with suppliers, customers and business partners as technological advancements have significantly impacted the traditional mediums of communication (i.e. door-to-door sales). For instance, the development of innovative online web-based shops (e-commerce) with product catalogues that consumers can browse from has altered the conventional platform of selling a manufacturer's goods and services facilitated by distributors in the past (Vohringer, 2014). Furthermore, the lack of personal interaction or human affinity inhibits a climate of trust which is important in B2B relationships (Mudambi \& Aggarwal 2003, p. 321). The study of $\mathrm{B} 2 \mathrm{~B}$ relationships are important because the good relations that are developed are implied to lead to positive outcomes such as increase in sales (Huntley, 2006), better performance (Ural, 2009; Wang \& Yang, 2013), customer loyalty (Liu, Guo \& Lee, 2011) and purchase intentions (Kim, Ko \& James, 2011).

B2B relationships is widely studied in literature of relationship marketing, supply chain management and transaction cost economics. Ali and Larimo (2016) and Huo et al. (2016) have noted that studies taking only a single perspective is inadequate to derive practical and meaningful implications based on the theories that are applied. Hence, the research takes a general perspective by emphasising on the B2B relationships in the context of an industrial business environment.

\subsubsection{Trust, Commitment and Satisfaction}

Trust - Morgan and Hunt (1994, p. 23) define trust "as existing when one partner has confidence in an exchange partner's reliability and integrity". Trust, commitment and satisfaction are constructs which are causally related to one another. However, these constructs are conceptualised in the research as dimensions of a higher order construct which is relationship quality instead of testing the causality among them. Trust is a relational construct that exhibits influence on how conflict is perceived between exchange partners (Morgan \& Hunt, 1994). When there is a lower level of social relationship, there is a lower level of trust among exchange partners (Ford, 1980). Alternatively, Mudambi and Aggarwal (2003) argues that technology advancements in which information is communicated online have override the way relationships are developed. Hence, it is possible that $\mathrm{B} 2 \mathrm{~B}$ relationships today that rely heavily on technology has replaced the conventional social interactions that is essential in building a climate of trust. On the other hand, Procter and Ackroyd (1998) have identified that trust leads to an increase in commitment, and satisfaction which leads to lower level of opportunistic behaviour between firms. When a partner feels doubtful of the other actions that are opportunistic, trust is severed apart from commitment.

A distributor's trust towards the manufacturer is an antecedent to a distributor's intention to achieve good relationship success (Wang \& Yang, 2013) and also with the manufacturer (Vázquez-Casielles, Iglesias \& Varela-Neira, 2017). In short, presence of trust between firms (manufacturer - distributor, distributor - manufacturer) can lead to lower level of opportunism (Ryu, Min \& Zushi, 2008; Ali \& Larimo, 2016) and better organisational performance (Wang \& Yang, 2013). 


\section{HOLISTICA Vol 11, Issue 3, 2020, pp.59-87}

Commitment - In the study of commitment - trust theory of relationship marketing, Morgan and Hunt (1994, p. 23) conceptualise commitment as "a belief within exchange partners that the relationship shared is so important that both would exert a high degree of effort in maintaining it". Ford (1980) denotes that when a company begins to commit to a supplier, the organisation will be unwilling to face uncertainty again by considering alternative vendors in the market. This then leads to facilitating a good and long-term relationship between B2B's (manufacturer - distributor - customer). Partners that are committed to one another are able to forge a good relationship over time. Joshi and Stump (1999) find commitment in a manufacturer and supplier relationship is negatively associated with opportunism. For instance, manufacturers who exercise opportunistic behaviour increase the tendency for distributors to source for other manufacturers whom they can commit to work with for the long term.

Meanwhile from a manufacturer's point of view, Sánchez, Vijande and Gutiérrez (2011) note that commitment is positively related to loyalty in distributors and hence predicting a long-term relationship. As a result, distributors will continue to sell the manufacturer's products or services more that can be translated into positive financial performance.

Satisfaction - Customer satisfaction in a distributor and customer relationship is important as it is suggested to reduce customer opportunism (Chu, Gerstner and Hess, 1998). Meanwhile, Wang and Yang (2013) have found that opportunism between a manufacturer and distributor leads to a lower overall satisfaction of both firms towards the relationship and ultimately resulting in poor firm performance. $\mathrm{Ng}$ (2012) on the other hand posits that a high level of mutual satisfaction is imperative to maintain sustainable relationships. Karyose, Astuti and Ferdiansjah (2017) find that the excellent performance of the bank staff was a form of service that improved customer satisfaction towards the bank's products and services. This implies that satisfaction leads to a reciprocal action that instils a good mutual feeling of working with the partner. Hence, satisfaction is achieved in a way by meeting the expectations of the exchange partner that is important in a B2B relationship.

\subsubsection{Information sharing}

Information sharing is another aspect of relationship marketing that is closely related to trust, commitment and satisfaction. Day (1992) suggests that information sharing is vital to build relationships with customer for long term prospects. The success of a partnership between firms is when communication is existent (Barber, 2003), while strategic information is shared between the distributor and manufacturer (Wang \& Yang, 2013; Ali \& Larimo, 2016). Information sharing is able to foster an environment of trust and satisfaction (Bigne \& Blesa, 2003), allowing businesses to transact harmoniously on equal footing by understanding each other's expectation from the relationship better (Nguyen \& Nguyen, 2014). Meanwhile, achievement of information equilibrium between firms is able to predict to a certain extent a positive association with opportunism (Williamson, 1973). Similarly, a higher degree of information exchange between an exporter and an 
importer predicts a higher level of business interaction that eventually leads to firm performance (Ural, 2009).

\subsubsection{B2B Relationship Quality}

Morgan and Hunt (1994, p. 22) define relationship marketing as "all marketing activities directed towards establishing, developing and maintaining successful relational exchanges". On a B2B level, it is imperative for firms to build good relationships with their partners (suppliers or customers) because a high-quality relationship is able to predict increase in sales and recommendation by word-of-mouth for a firm (Huntley, 2006). Meanwhile, Liu et al. (2011) find empirical support whereby firms focusing on building long term relationships result in an improved relationship quality that eventually leads to customers exhibiting a higher degree of loyalty to stick with their supplier as a preferred business partner. On the other hand, Kim, Ko and James (2011) states that a good relationship shared between a sports team with the fans (customer) not only positively affects sport consumption behaviour related to the team but also positively influences the purchase of the sponsor's product which can be in the form of sales. In other words, a good relationship in an exchange between partners leads to higher firm performance (Wang \& Yang, 2013; Nasim \& lqbal, 2019). Business relationships are gaining significance in business studies due to the norms that are shared among business partners in an exchange that is implied to constitute to a successful partnership. The quality of a relationship between business organisations would consist of the following aspects but not limited to values such as trust, commitment, satisfaction, information sharing and goal congruence.

Table 1 Dimensions of relationship quality

\begin{tabular}{|c|c|c|}
\hline Author(s) & Constructs & Relationship context \\
\hline $\begin{array}{c}\text { Bennett and } \\
\text { Barkensio (2004) }\end{array}$ & Trust, commitment, benevolence & $\begin{array}{c}\text { Charity organisations } \\
\text { - beneficiaries }\end{array}$ \\
\hline $\begin{array}{l}\text { Rauyruen and } \\
\text { Miller (2005) }\end{array}$ & Service quality, trust, commitment, satisfaction & Business - business \\
\hline Huntley (2006) & Technology, time, economic, social, partnership & Buyer - seller \\
\hline Ural (2009) & $\begin{array}{l}\text { Information sharing, communication quality, } \\
\text { long-term orientation, satisfaction }\end{array}$ & Exporter - importer \\
\hline $\begin{array}{l}\text { Mysen, Svensson } \\
\text { and Payan (2011) }\end{array}$ & Trust, commitment, opportunism & Business - business \\
\hline $\begin{array}{l}\text { Liu, Guo and Lee } \\
\text { (2011) }\end{array}$ & Trust, satisfaction & $\begin{array}{l}\text { Service provider - } \\
\text { customers }\end{array}$ \\
\hline $\begin{array}{l}\text { Kim, Ko and James } \\
\text { (2011) }\end{array}$ & Trust, commitment, self-connection, reciprocity & Business - consumer \\
\hline $\begin{array}{l}\text { Nasim and lqbal } \\
\qquad(2019)\end{array}$ & $\begin{array}{l}\text { Information sharing, communication, long term } \\
\text { relationship orientation, satisfaction with the } \\
\text { relationship }\end{array}$ & Students \\
\hline
\end{tabular}

Source: Author's synthesis 


\section{HOLISTICA Vol 11, Issue 3, 2020, pp.59-87}

Based on past researches by Morgan and Hunt (1994), Bennett and Barkensjo (2004), Huntley (2006), Mysen, Svensson, and Payan (2011), Ou, Shih, Chen and Wang (2011) and Liu, Guo and Lee (2011), relationship quality is measured as a higher order construct (HOC) that consist of multiple lower order constructs (LOC) or namely, dimensions. Table 1 is a summary of the different dimensions of the relationship quality construct from past researches. These authors have implied that the operationalization of relationship quality as a higher order construct is idiosyncratic and is heavily influenced by the context of the research. Higher order models or hierarchical component models reduces the number of relationships in the structural model allows for better understanding (Hair et al., 2017).

B2B relationship quality as a multi-dimension construct in this model takes the form of an aggregate model where Law, Wong and Mobley (1998, p. 745) suggest as "a composite formed from its dimensions". Trust, commitment and satisfaction are among the widely used constructs that are conceptualised to form a higher order construct, relationship quality. A good relationship between the customer and distributor can be apparent from the feelings of trust and commitment that is shared (Bennett and Barkensjo, 2004).

This is evident from the work of the authors with reference to Table 1 above. In this research, information sharing is incorporated as the fourth dimension that makes up the B2B relationship construct. Nasim and Iqbal (2019) conceptualise relationship quality as a HOC consisting of four dimensions namely, information sharing, communication, long term relationship and satisfaction. Similarly, Ural (2009) conceptualise relationship quality as a HOC consisting of information sharing, communication quality, long-term orientation and satisfaction. Ural (2009) also find empirical support that information sharing is able to lead to positive performance outcomes. Zhang, Cavusgil and Roath (2003) imply that information exchange is important in relationships because they entail the bilateral expectations that partners will share useful information. The use of multi-dimensional constructs is observed more often in the study of psychology when there are various traits that make up another HOC (Howard \& Crayne, 2019).

Although Mysen, Svensson and Payan (2011) have included opportunism as a dimension of relationship quality, opportunism is treated separately in this research because the research seeks to explain the phenomenon between B2B relationship quality, opportunism and firm performance. As above mentioned, the conceptualisation of relationship quality is highly dependent on the nature of the research.

Building on the work of the previous authors, it is imperative for businesses to actively engage, interact with their exchange partners (i.e. suppliers and customers) as relationship marketing suggests, the research hence incorporates information sharing (Nguyen, TM and Nguyen, TD 2014) as an additional dimension to measure relationship quality. Hence, the research conceptualises relationship quality as a higher order construct with four dimensions encompassing trust, commitment, satisfaction, and information sharing.

Drawing from the above, the research hypothesises the following: 
$\mathrm{H} 1$ : B2B relationship quality is negatively related to opportunism.

$\mathrm{H} 2$ : $\mathrm{B} 2 \mathrm{~B}$ relationship quality is positively related to firm performance.

\subsubsection{Opportunism and firm performance}

Opportunism is defined by Williamson (1973, p. 317) as, "an effort to realize individual gains through a lack of candour or honesty in transactions". The term opportunism is an important element in the study of transaction cost economics and relationship marketing; where transaction-specific investments in human and physical capital within economic activities are involved (Williamson, 1979). Firms are inclined to act opportunistically should the conditions prove to be both feasible and profitable (John 1984, p. 278). The opportunism construct that has been extensively studied in the past have proven to a certain extent whereby negative outcomes such as manufacturer's intention to not extend the relationship with a distributor (Ono and Kubo, 2011), lower trust, satisfaction, and commitment (Morgan and Hunt, 1994; Williamson, 1973; John, 1984) were predicted.

Opportunism can also be in the form of providing misleading information (John, 1984) or shirking by putting little effort to fulfil the contractual obligations (Eisenhardt, 1989). Meanwhile, a B2B transaction can be in the form of supplying goods to another organisation or the outsourcing of an internal function to an external party. 'Take for example in a manufacturer - distributor relationship setting, there is a delegation of work by the manufacturer (contractee) to the distributor (contractor) in sales and marketing of their products and services. There exists a risk that the distributor may not be fulfilling or honouring the contractual obligations by representing a competing product line. In this research, opportunism is viewed as an action that is condoning if the conditions are both feasible and profitable for another (John, 1984). Similarly, perceptions of opportunistic behaviour by the distributor towards the manufacturer is able to predict reduced firm performance (Vázquez-Casielles, Iglesias \& Varela-Neira, 2017). In other words, it can be implied that opportunistic action that is actually exhibited or perceived by either party would result in an overall reduced value may it be economic or strategic. Although past researchers have found empirical evidence on how opportunism can play a value reduction role in B2B relationships (Bhattacharya, Singh \& Nand, 2015; Ali \& Larimo, 2016) the empirical evidence on its impact towards firm performance of organisations is still lacking.

Yam and Chan (2015) hypothesised that increased levels of information sharing between partners would predict a higher level of opportunism, which statistical results have proven otherwise instead. It can be comprehended that higher levels of information sharing predicted lower level of opportunism as partners unite and align their efforts for long term benefits from relationship success.

Vázquez-Casielles, Iglesias and Varela-Neira (2017) put forth that passive and active opportunistic behaviour of manufacturers perceived by distributors will cause them to be wary of the relationship specific investments towards the relationship. Wang and Yang (2013) find that there is a negative relationship between inter-firm opportunism and 
HOLISTICA Vol 11, Issue 3, 2020, pp.59-87

organisational performance. Jack, Powers and Skinner (2010) imply that a customer may act opportunistically by purchasing products for a single time use and return it to claim for a warranty for various unethical reasons. The research then hypothesises:

H3: Opportunism is negatively related to firm performance.

Opportunism was found to be detrimental towards firm performance as mentioned by Wang and Yang (2013). Here, the research suggests that there is a possible intervening effect of opportunism on B2B relationship quality and firm performance. Hence, the following is hypothesised to investigate the potential mediating role of opportunism between $\mathrm{B} 2 \mathrm{~B}$ relationship quality and firm performance.

H4: Opportunism mediates the relationship between B2B relationship quality and firm performance.

\subsubsection{Proposed Conceptual Model}

Based on the developed hypotheses, the following conceptual model in Figure 2 below is proposed.

Figure 2 Proposed Conceptual Model

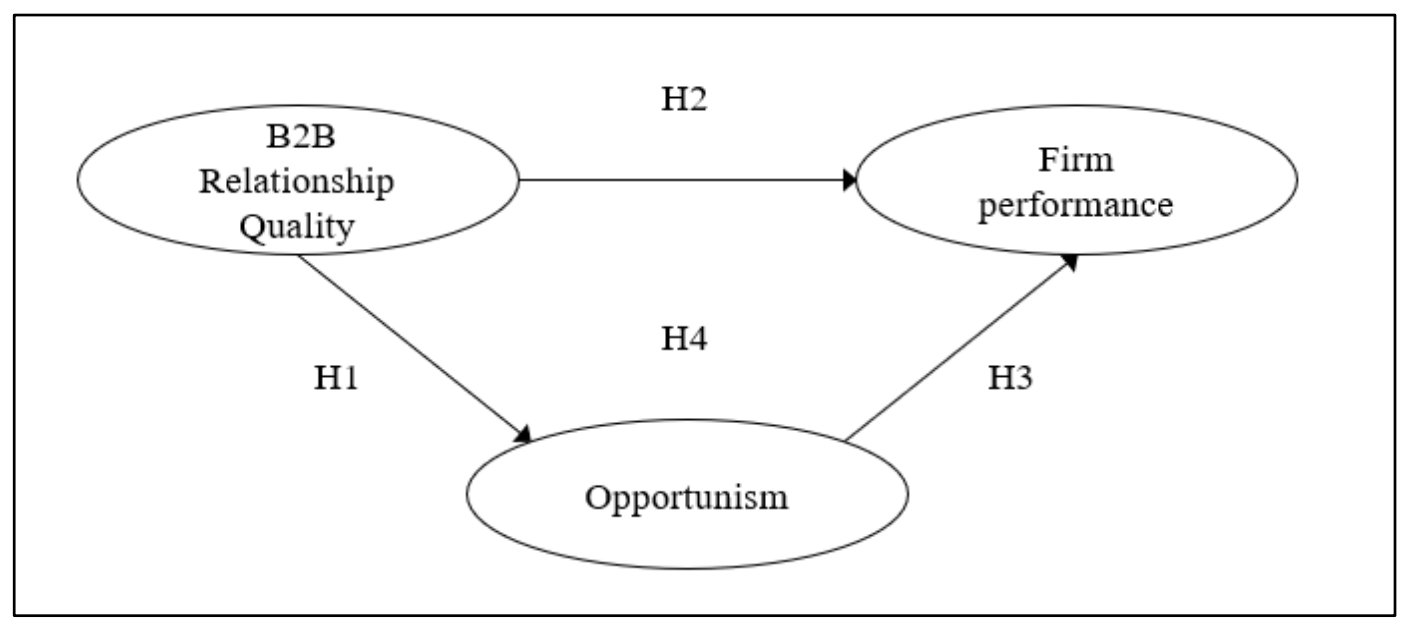

Source: Author's synthesis

\section{Tables}

\subsection{Research Design}

The research adopts a positivist, deductive approach that is concerned in developing and testing the hypothesised relationships based on existing theories (Saunders, Lewis \& Thornhill, 2009, p. 124) The process of relationship development is in fact longitudinal in nature according to Emerson (1976). This is because there are different stages in the 
development of a relationship that leads to different outcomes (Ford, 1980). Take for example a relationship between two new and unfamiliar companies in a transaction, Cropanzano and Mitchell (2005) implied that the exchange would alter the nature of the relationship. Subsequently, should a good relationship be developed as a result of the exchange, the relationship which gets better after a certain time would be able to alter the nature of the exchange. However, data collection will be cross-sectional by means of a survey where quantitative data will be gathered to test the hypothesised relationships. The research follows the work of Bennett and Barkensjo (2004), Huntley (2006), and O'Cass, Ngo and Siahtiri (2015) whereby a cross-sectional design is used to focus on the $\mathrm{B} 2 \mathrm{~B}$ relations of firms at a single point in time.

\subsection{Sampling and data collection}

The objective of the research is to empirically determine the influences of B2B relationship quality and opportunism on firm performance in the context of an industrial business environment. The research employs a non-probability, judgmental and snowball sampling technique whereby the sample was carefully picked to represent the population of the study. This method of sampling allows the researcher to select the sample that would best represent and answer the research questions (Saunders, Lewis \& Thornhill, 2009, p. 237). Subsequently, snowball sampling allows the researches to identify more similar respondents from the referrals of the initially identified sample (Saunders, Lewis \& Thornhill, 2009, p. 240). As such, employees or employers of various organisations within the industrial business environment that were initially identified for the study were also requested to recruit other members of their organisation or associates within the industry to participate in the survey. A general rule of thumb for the minimum sample size should be at least 10 times the number of constructs in the study (Darlington \& Hayes, 2017, p. 520).

Primary data was collected by means of an online questionnaire survey via Google forms. A link to the survey was distributed to the employees or employers of various business organisations via WhatsApp, LinkedIn and email accompanied by a cover letter. The data collection method for this research employs the use of a self-administered questionnaire. The gathered data will be analysed via PLS-SEM, a statistical analysis tool for quantitative studies. Among the prominent reasons of using PLS-SEM is the use of small sample sizes (Ringle et al., 2012).

\subsection{Questionnaire design}

The questionnaire consists of 35 questions in total in which questions 1-6 were demographic questions while remaining 7-35 were for measuring the 6 different constructs in the study. The complete questionnaire sample can be referenced from Appendix B. The questions to measure "trust" and "information sharing" have been adapted from Pooe, Mafini and Loury-Okoumba (2015), "commitment" from Gilboa, Seger-Guttmann and Mimran (2019), "satisfaction" from Vázquez-Casielles, Iglesias and Varela-Neira (2017), "opportunism" from Huo, Ye and Zhao (2015), and lastly "firm performance" from O'Cass, Ngo and Siahtiri (2015). The questions were modified to fit 
the context of the study while the scale was standardized by using a 7 - point Likert scale ranging from 1 (strongly disagree) to 7 (strongly agree) for all constructs except for "firm performance" whereby it ranges from 1 (very poor) to 7 (very good). Meanwhile, no reverse coded questions were identified from the adopted questions. The questionnaire will target working adults ranging from executive - senior manager and above levels in the industrial environment within Malaysia. A total of 175 links to the online survey were sent to employees / employers of various business organisations within the industrial environment. After 4 weeks, a total of 98 usable response making up a response rate of $56.0 \%$ were collected out of the 175 links that were sent.

All constructs from the adapted studies above yielded composite reliability (CR) scores that were above the recommended thresholds. For example, the reliability and validity scores for constructs adapted from the study of Pooe, Mafini and Loury-Okoumba (2015) were 0.96 for trust and 0.95 for information sharing. Meanwhile, the CR score for commitment adapted from Gilboa, Seger-Guttmann and Mimran (2019) was 0.91. CR score for satisfaction adapted from Vázquez-Casielles, Iglesias and Varela-Neira (2017) was 0.97. Opportunism construct adapted from Huo, Ye and Zhao (2015) had a CR score of 0.936. Lastly, CR score for firm performance construct adapted from O'Cass, Ngo and Siahtiri (2015) was 0.91.

\section{Data Analysis Methods}

\subsection{Non-response bias analysis}

Practically, it cannot be expected that all targeted respondents of a survey would participate. In the event the respondents refuse to take part in the survey, it would lead to the sample not being representative of the population (Saunders, Lewis and Thornhill 2009 , p. 220). In other words, there is a concern of non-response bias. Non-response bias is an event where targeted respondents of a survey who did not respond make up a significant effect towards data collection (Glen, 2013). The error can be tested via independent sample t-test for measurements with two options.

\subsection{Common method variance (CMV)}

Bagozzi, Yi and Phillips (1991) define method variance as the "variance that is attributable to the measurement method rather than to the construct of interest". Common method bias will lead to the wrong conclusion of hypothesis due to single source data that is used to account for both the predictor and outcome (Podsakoff et al. 2003). In other words, the same respondent of the survey answers the questions of the different constructs in the study. To test for CMV, the evaluation can be tested via the Harman's single factor test according to Podsakoff and Organ (1986).

\subsection{Multicollinearity}

Multicollinearity exist when there is a high correlation between two or more independent variables in the research. When two or more variables are highly correlated in the study, 
it indicates that both variables are the same in explaining the variance of the dependent variable and omitting either one will not have any significant effect towards the relationship that is studied (Field 2014, p. 324). In the proposed conceptual model of the research, if all constructs are highly correlated, it will be difficult to assess which construct would significantly affect firm performance. A measurement of multicollinearity issue is the tolerance value and variance inflation factor (VIF).

\subsection{Reliability}

Reliability is a measure of the internal consistency of measured data (Field, 2014). It addresses how a specific construct can derive the same result at different points in time. As such Cronbach's alpha, $\alpha$ is a commonly used measurement of reliability. However, there are flaws to this measurement of reliability as it assumes all of the measured indicators are equally related to the construct. Hence, researchers turn to the measure of composite reliability (CR) for measure of internal consistency as the indicator loadings are accounted for (Ramayah et al. 2018, p.82). Garson (2016, p. 63) implied that this measure of internal consistency may be preferred rather than the Cronbach's alpha as it may over or underestimate scale reliability.

\subsection{Validity}

Validity is a test of how well the construct is able to measure what it is intended to measure (Sekaran and Bougie 2016, p. 227). Validity of constructs are assessed based on the convergent validity and discriminant validity criteria. Convergent validity is a measure of the extent which indicators reflecting a construct converging in relation to indicators measuring other constructs (Ramayah et al. 2018, p. 83). Alternatively, convergent validity is achieved if the constructs account for at least $50 \%$ of the variance explained by its indicators (Garson 2016, p. 65). Measures of convergent validity are the composite reliability scores of the constructs. Meanwhile, discriminant validity is the degree which the indicators differentiate among constructs (Ramayah et al. 2018, p.84). Discriminant validity can be assessed from the cross loadings, Fornell \& Larcker's criterion and the Heterotrait-Monotrait ratio of correlations (HTMT).

\subsection{Mediation Analysis}

Mediation occurs when there is a third variable or intervening variable commonly known as a mediator variable, intervenes the relationship between an independent variable and a dependent variable (Hair et al. 2017, p. 245). For a significant mediation relationship, Field (2014, p. 410), states that there are four conditions that must be tested.

- $\quad$ The independent variable must significantly predict the dependent variable (1)

- $\quad$ The independent variable must significantly predict the mediating variable (2)

- $\quad$ The mediating variable must significantly predict the dependent variable (3)

- $\quad$ The independent variable must predict the dependent variable less strongly in model (3) compared to model (1) 
Mediated regression analysis involves the assessment of the size of indirect effect and its confidence interval bias (Field 2014, p. 419). In SmartPLS 3.0, mediation can be assessed by conducting a bootstrapping method to analyse the significance of the direct relationships (t-values) and confidence interval bias of the hypothesised mediation relationship (Ramayah et al., 2018 p. 206).

\subsection{Structural model Analysis}

Following the guidelines of Ramayah et al. (2018), the analysis of the structural model includes the analysis of collinearity, path coefficients and significance of relationships, coefficient of determination, $R^{2}$, Effect size, $f^{2}$ and Predictive relevance, $Q^{2}$. The significance and relevance of the structural model relationship can be assessed in SmartPLS 3.0 using the bootstrapping method (Ramayah et al. 2018, p. 153). By running bootstrapping, researchers would be able to assess the effect of the various hypothesised relationships in the structural model. At a significance level of $0.05, T$-statistics value > 1.96 indicates that there is a significant relationship between two related variables of the study (Hair et al. 2017). The coefficient of determination, $R^{2}$ is a measure of the structural model's predictive accuracy. Alternatively, it is the combination of the effects from the independent variables of the study on the dependent variable. Below is the guideline adopted from Cohen (1988) on assessing the predictive power of the structural model.

\subsection{Common Method Variance Analysis}

The presence of CMV in a research will lead to wrong conclusion of the hypothesis and outcome of the study as indicated by Podsakoff et al. (2003). One of the methods proposed to confine the issues arising from CMV is by conducting Harman's single factor test (Podsakoff and Organ, 1986). The statistical findings yielded a variance \% of 35.823 (See Table 2) which is well below the threshold at $50 \%$ and indicates no presence of common method bias in the study.

Table 2 Common Method Variance

\begin{tabular}{ccccccc}
\hline \multirow{2}{*}{ Component } & \multicolumn{3}{c}{ Initial Eigenvalues } & \multicolumn{3}{c}{ Extraction Sums of Squared Loadings } \\
\cline { 2 - 6 } & Total & $\begin{array}{c}\text { \% of } \\
\text { Variance }\end{array}$ & $\begin{array}{c}\text { Cumulative } \\
\%\end{array}$ & Total & $\begin{array}{c}\% \text { of } \\
\text { Variance }\end{array}$ & $\begin{array}{c}\text { Cumulative } \\
\%\end{array}$ \\
\hline 1 & 10.389 & 35.823 & 35.823 & 10.389 & 35.823 & 35.823 \\
\hline
\end{tabular}

Source: Author's synthesis

Based on Table 3, the Levene's test for Equality of variance is not significant $(F=1.401$, Sig. > 0.05). indicates that there is no significant difference between the early and late respondents. It can be concluded there is a difference between the two groups and there is no concern of non-response bias.

Table 3 Non-responsive Bias Analysis 
HOLISTICA Vol 11, Issue 3, 2020, pp.59-87

\begin{tabular}{|c|c|c|c|c|c|c|c|c|c|c|}
\hline & & \multicolumn{2}{|c|}{$\begin{array}{l}\text { Levene's } \\
\text { Test for } \\
\text { Equality of } \\
\text { Variances }\end{array}$} & \multicolumn{7}{|c|}{ t-test for Equality of Means } \\
\hline & & \multirow[t]{2}{*}{$\mathbf{F}$} & \multirow[t]{2}{*}{ Sig. } & \multirow[t]{2}{*}{$t$} & \multirow[t]{2}{*}{ df } & \multirow{2}{*}{$\begin{array}{l}\text { Sig. } \\
(2- \\
\text { taile } \\
\text { d) }\end{array}$} & \multirow[t]{2}{*}{$\begin{array}{c}\text { Mean } \\
\text { Differen } \\
\text { ce }\end{array}$} & \multirow{2}{*}{$\begin{array}{c}\text { Std. } \\
\text { Error } \\
\text { Differen } \\
\text { ce }\end{array}$} & \multicolumn{2}{|c|}{$\begin{array}{c}\text { 95\% Confidence } \\
\text { Interval of the } \\
\text { Difference }\end{array}$} \\
\hline & & & & & & & & & Lower & Upper \\
\hline \multirow{9}{*}{$\frac{T_{\bar{P}} \mathrm{~F}}{\mathrm{P}}$} & Equal & 1.40 & .23 & - & 96 & .918 & -.06034 & .58299 & - & 1.0968 \\
\hline & Varianc & 1 & 9 & .10 & & & & & 1.2175 & 7 \\
\hline & es & & & 4 & & & & & 6 & \\
\hline & Assume & & & & & & & & & \\
\hline & $d$ & & & & & & & & & \\
\hline & Equal & & & - & 77.80 & .919 & -.06034 & .59497 & - & 1.1242 \\
\hline & Varianc & & & .10 & 5 & & & & 1.2448 & 0 \\
\hline & es not & & & 1 & & & & & 9 & \\
\hline & $\begin{array}{c}\text { Assume } \\
\mathrm{d}\end{array}$ & & & & & & & & & \\
\hline
\end{tabular}

Source: Author's synthesis

\subsection{Multicollinearity Analysis}

The presence of multicollinearity among the variables would create a problem in distinguishing them. Results of the test indicate that there is no multicollinearity between the constructs. With reference to Allen, Bennett and Heritage (2014, p.188), the tolerance values tabulated in Table 8 above met the criteria (Tolerance $>0.1, \mathrm{VIF}<5$ ). This indicates that multicollinearity does not exist between the independent variables which may render their individual importance as a predictor (see Table 4).

Table 4 Multicollinearity test

\begin{tabular}{|c|c|c|c|c|c|c|c|c|}
\hline \multicolumn{2}{|c|}{ Model } & \multicolumn{2}{|c|}{$\begin{array}{l}\text { Unstandardized } \\
\text { Coefficients }\end{array}$} & \multirow{2}{*}{$\begin{array}{c}\text { Standardized } \\
\text { Coefficients }\end{array}$} & \multirow[t]{2}{*}{$t$} & \multirow[t]{2}{*}{ Sig. } & \multicolumn{2}{|c|}{$\begin{array}{c}\text { Collinearity } \\
\text { Statistics }\end{array}$} \\
\hline & & $B$ & $\begin{array}{l}\text { Std. } \\
\text { Error }\end{array}$ & & & & Tolerance & VIF \\
\hline \multirow[t]{6}{*}{1} & (Constant) & 9.318 & 3.136 & & 2.972 & .004 & & \\
\hline & T_TR & .008 & .090 & .012 & .088 & .930 & .506 & 1.975 \\
\hline & T_COM & .108 & .139 & .098 & .777 & .439 & .567 & 1.764 \\
\hline & T_SAT & .258 & .156 & .259 & 1.661 & .100 & .375 & 2.669 \\
\hline & T_IS & .078 & .090 & .122 & .872 & .385 & .468 & 2.138 \\
\hline & T_OP & .042 & .042 & .106 & 1.004 & .318 & .810 & 1.234 \\
\hline
\end{tabular}

Source: Author's synthesis 


\subsection{Normality Test Analysis}

With reference to Table 5, values of skewness and kurtosis are within the recommended guidelines (Hair et al. 2017, p. 77). Values of skewness and kurtosis are neither less than 1 or more than +1 . This implies that there is no concern of non-normal distribution within the sample.

Table 5 Normality Test

\begin{tabular}{cccccc}
\hline & $\mathbf{N}$ & \multicolumn{2}{c}{ Skewness } & \multicolumn{2}{c}{ Kurtosis } \\
\cline { 2 - 6 } & Statistic & Statistic & Std. Error & Statistic & Std. Error \\
\hline T_TR & 98 & -.194 & .244 & .046 & .483 \\
\hline T_COM & 98 & -.432 & .244 & -.835 & .483 \\
\hline T_SAT & 98 & .074 & .244 & -.265 & .483 \\
\hline T_IS & 98 & .297 & .244 & -.543 & .483 \\
\hline T_OP & 98 & .615 & .244 & -.065 & .483 \\
\hline T_FP & 98 & .260 & .244 & -.386 & .483 \\
\hline Valid N (listwise) & 98 & & & &
\end{tabular}

Source: Author's synthesis

\subsection{Descriptive Statistics}

With reference to Table 6, majority of the population in terms of the respective demographic variables are male respondents making up $83.7 \%$ of the population. In terms of age group respondents between $21-30$ years old make up $49 \%$ of the population followed by $31-40$ years old (24.5\%), $41-50$ years old (15.3\%) and $51-60$ years old (11.2\%). It is observed that more than half $(57 \%)$ of the population possess an academic qualification of Bachelor's Degree. Approximately half of the population are above the age of 30-year-old. Possess a Bachelor's Degree qualification. Meanwhile, about $55.1 \%$ of the population are employed in a manufacturing organisation followed by a supplier organisation (23.5\%), distributor organisation (18.4\%); while the remaining $3.1 \%$ are from other types such as a service organisation. With respect to the position level, $70.4 \%$ of the population are senior executive levels and above. Furthermore, more than half of the population (57.1\%) have mid-senior level and above employment experience. In short, this implies that majority of the respondents are well educated, within the manufacturing industry and are experienced within their field.

Following the guidelines of Sarstedt et al. (2019), this approach for higher order models consist of two stages in which the first stage is concerned with the measurement model of the LOC's. Since the B2B Relationship Quality construct is a higher order construct that is formed from its lower order constructs or dimensions, the indicators of the LOC's are repeated in the HOC in the first stage of this approach. The second stage is concerned with the structural model whereby the latent variable scores (LVS) of the LOC's will be 
HOLISTICA Vol 11, Issue 3, 2020, pp.59-87

computed as indicators of the HOC. In the measurement model, it is observed that the indicators of the LOC's are reflectively measured.

Table 6 Descriptive Statistics

\begin{tabular}{|c|c|c|c|}
\hline Demographic variables & Description & Frequency & Percentage \% \\
\hline \multirow[t]{2}{*}{ Gender } & Male & 82 & 83.7 \\
\hline & Female & 16 & 16.3 \\
\hline \multirow[t]{4}{*}{ Age group } & 21 - 30 years old & 48 & 49.0 \\
\hline & $31-40$ years old & 24 & 24.5 \\
\hline & $41-50$ years old & 15 & 15.3 \\
\hline & $51-60$ years old & 11 & 11.2 \\
\hline \multirow[t]{5}{*}{ Highest academic qualification } & Diploma & 18 & 18.4 \\
\hline & Advanced Diploma & 1 & 1.0 \\
\hline & Bachelor's Degree & 57 & 58.2 \\
\hline & Master's Degree & 18 & 18.4 \\
\hline & Other & 4 & 4.1 \\
\hline \multirow[t]{4}{*}{ Role of organization } & Supplier & 23 & 23.5 \\
\hline & Distributor & 18 & 18.4 \\
\hline & Manufacturer & 54 & 55.1 \\
\hline & Other & 3 & 3.1 \\
\hline \multirow[t]{5}{*}{ Position level } & Junior Executive & 29 & 29.6 \\
\hline & Senior Executive & 23 & 23.5 \\
\hline & Manager & 25 & 25.5 \\
\hline & Senior Manager & 20 & 20.4 \\
\hline & Other & 1 & 1.0 \\
\hline \multirow[t]{4}{*}{ Employment experience } & Entry level & 25 & 25.5 \\
\hline & Associate & 17 & 17.3 \\
\hline & Mid - Senior Level & 45 & 45.9 \\
\hline & Director & 11 & 11.2 \\
\hline
\end{tabular}

Source: Author's synthesis

Table 7 below is a summary of the indicator loadings, average variance extracted (AVE) scores and composite reliability (CR) scores of the constructs. All the indicators have loadings above 0.7 , except for TR1 with a loading of 0.644 which was deleted as it did not meet the criteria. Upon removal, it was observed that the AVE for Trust increased. From Table 10, it can be observed that all constructs have met the satisfactory level of AVE result of $>0.5$. Meanwhile, all constructs have also met the threshold for $C R>0.8$. Based on the results, the constructs have met the reliability and convergent validity requirement.

Table 7 Loadings, AVE and CR (Measurement Model) 
HOLISTICA Vol 11, Issue 3, 2020, pp.59-87

\begin{tabular}{|c|c|c|c|c|c|}
\hline $\begin{array}{l}\text { First order } \\
\text { construct }\end{array}$ & $\begin{array}{l}\text { Second } \\
\text { order } \\
\text { construct }\end{array}$ & Item & Loadings & AVE & CR \\
\hline \multirow[t]{5}{*}{ Trust } & 30 & TR2 & 0.784 & 0.647 & 0.901 \\
\hline & 20 & TR3 & 0.725 & & \\
\hline & & TR4 & 0.824 & & \\
\hline & & TR5 & 0.846 & & \\
\hline & & TR6 & 0.837 & & \\
\hline \multirow[t]{4}{*}{ Commitment } & & COM1 & 0.853 & 0.760 & 0.927 \\
\hline & & $\mathrm{COM} 2$ & 0.872 & & \\
\hline & & COM3 & 0.917 & & \\
\hline & & COM4 & 0.844 & & \\
\hline \multirow[t]{4}{*}{ Satisfaction } & & SAT1 & 0.774 & 0.680 & 0.895 \\
\hline & & SAT2 & 0.878 & & \\
\hline & & SAT3 & 0.850 & & \\
\hline & & SAT4 & 0.793 & & \\
\hline \multirow{10}{*}{$\begin{array}{c}\text { Information } \\
\text { Sharing }\end{array}$} & & IS1 & 0.763 & 0.657 & 0.920 \\
\hline & & IS2 & 0.774 & & \\
\hline & & IS3 & 0.815 & & \\
\hline & & IS4 & 0.803 & & \\
\hline & & IS5 & 0.870 & & \\
\hline & & IS6 & 0.835 & & \\
\hline & $\begin{array}{c}\text { Relationship } \\
\text { quality }\end{array}$ & Trust & 0.775 & 0.695 & 0.901 \\
\hline & & Commitment & 0.791 & & \\
\hline & & Satisfaction & 0.897 & & \\
\hline & & $\begin{array}{l}\text { Information } \\
\text { Sharing }\end{array}$ & 0.865 & & \\
\hline \multirow[t]{5}{*}{ Opportunism } & & OP1 & 0.841 & 0.717 & 0.951 \\
\hline & & OP2 & 0.911 & & \\
\hline & & OP3 & 0.906 & & \\
\hline & & OP4 & 0.892 & & \\
\hline & & OP5 & 0.912 & & \\
\hline \multirow[t]{3}{*}{ Firm Performance } & & FP1 & 0.830 & 0.797 & 0.910 \\
\hline & & FP2 & 0.838 & & \\
\hline & & FP3 & 0.856 & & \\
\hline
\end{tabular}


Source: Author's synthesis

Next, the discriminant validity of the model is assessed. Using the Fornell \& Larcker Criterion, results in Table 8 above indicates that all constructs of the study have sufficient discriminant validity whereby the square root of AVE (diagonal) is larger than the correlations of the reflective constructs. To further assess the discriminant validity, cross loadings of the constructs were assessed.

Table 8 Fornell \& Larcker Criterion

\begin{tabular}{ccccccc}
\hline & Commitment & $\begin{array}{c}\text { Firm } \\
\text { Perf }\end{array}$ & $\begin{array}{c}\text { Info } \\
\text { Sharing }\end{array}$ & Opportunism & Satisfaction & Trust \\
\hline Commitment & 0.872 & & & & & \\
Firm Perf & 0.309 & 0.847 & & & & \\
Info Sharing & 0.579 & 0.332 & 0.811 & & & \\
Opportunism & -0.245 & -0.031 & -0.318 & 0.893 & & \\
Satisfaction & 0.585 & 0.371 & 0.696 & -0.382 & 0.825 & \\
Trust & 0.504 & 0.292 & 0.568 & -0.122 & 0.638 & 0.804 \\
\hline
\end{tabular}

Source: Author's synthesis

Assessing discriminant validity using the cross-loading criterion requires that the indicator loadings of the construct itself should be higher than the loadings on the other constructs of the study. Cross loading results in Table 9 indicates that discriminant validity has been achieved. To further assess for discriminant validity, the HTMT technique was used.

Table 9 Cross-loadings

\begin{tabular}{ccccccc}
\hline & Trust & Commitment & Satisfaction & $\begin{array}{c}\text { Info. } \\
\text { Sharing }\end{array}$ & Opportunism & $\begin{array}{c}\text { Firm } \\
\text { Perf }\end{array}$ \\
\hline TR2 & $\mathbf{0 . 7 9 6}$ & 0.435 & 0.544 & 0.444 & -0.076 & 0.214 \\
TR3 & $\mathbf{0 . 7 1 8}$ & 0.328 & 0.442 & 0.337 & -0.082 & 0.237 \\
TR4 & $\mathbf{0 . 8 3 0}$ & 0.432 & 0.623 & 0.543 & -0.142 & 0.275 \\
TR5 & $\mathbf{0 . 8 2 2}$ & 0.374 & 0.500 & 0.447 & -0.101 & 0.231 \\
TR6 & $\mathbf{0 . 8 0 6}$ & 0.426 & 0.428 & 0.486 & -0.066 & 0.212 \\
COM1 & 0.599 & $\mathbf{0 . 8 4 1}$ & 0.529 & 0.557 & -0.216 & 0.274 \\
COM2 & 0.428 & $\mathbf{0 . 8 6 6}$ & 0.420 & 0.431 & -0.125 & 0.254 \\
COM3 & 0.473 & $\mathbf{0 . 9 2 3}$ & 0.581 & 0.581 & -0.261 & 0.279 \\
COM4 & 0.392 & $\mathbf{0 . 8 5 6}$ & 0.501 & 0.425 & -0.222 & 0.259 \\
SAT1 & 0.527 & 0.499 & $\mathbf{0 . 7 5 2}$ & 0.562 & -0.190 & 0.201 \\
& & & & & & \\
\hline
\end{tabular}


HOLISTICA Vol 11, Issue 3, 2020, pp.59-87

$\begin{array}{lllllll}\text { SAT2 } & 0.602 & 0.379 & \mathbf{0 . 8 7 5} & 0.590 & -0.286 & 0.347 \\ \text { SAT3 } & 0.562 & 0.479 & \mathbf{0 . 8 5 5} & 0.605 & -0.383 & 0.309 \\ \text { SAT4 } & 0.453 & 0.584 & \mathbf{0 . 8 1 0} & 0.536 & -0.382 & 0.365 \\ \text { IS1 } & 0.467 & 0.632 & 0.560 & \mathbf{0 . 7 6 1} & -0.323 & 0.177 \\ \text { IS2 } & 0.471 & 0.474 & 0.559 & \mathbf{0 . 7 7 9} & -0.311 & 0.327 \\ \text { IS3 } & 0.428 & 0.425 & 0.581 & \mathbf{0 . 8 1 7} & -0.269 & 0.257 \\ \text { IS4 } & 0.333 & 0.356 & 0.451 & \mathbf{0 . 8 0 4} & -0.119 & 0.302 \\ \text { IS5 } & 0.532 & 0.467 & 0.591 & \mathbf{0 . 8 6 5} & -0.242 & 0.279 \\ \text { IS6 } & 0.515 & 0.437 & 0.615 & \mathbf{0 . 8 3 3} & -0.242 & 0.278 \\ \text { OP1 } & 0.007 & -0.073 & -0.232 & -0.178 & \mathbf{0 . 8 5 3} & -0.131 \\ \text { OP2 } & -0.127 & -0.242 & -0.375 & -0.321 & \mathbf{0 . 9 0 7} & -0.040 \\ \text { OP3 } & -0.088 & -0.226 & -0.353 & -0.328 & \mathbf{0 . 9 0 4} & 0.037 \\ \text { OP4 } & -0.083 & -0.249 & -0.333 & -0.271 & \mathbf{0 . 8 9 2} & -0.065 \\ \text { OP5 } & -0.129 & -0.252 & -0.392 & -0.278 & \mathbf{0 . 9 1 1} & 0.003 \\ \text { FP1 } & 0.246 & 0.310 & 0.314 & 0.297 & 0.022 & \mathbf{0 . 8 2 5} \\ \text { FP2 } & 0.212 & 0.202 & 0.270 & 0.249 & -0.120 & \mathbf{0 . 8 3 9} \\ \text { FP3 } & 0.243 & 0.222 & 0.341 & 0.298 & -0.048 & \mathbf{0 . 8 6 4} \\ \text { FP4 } & 0.287 & 0.290 & 0.337 & 0.274 & 0.000 & \mathbf{0 . 8 5 8}\end{array}$

Source: Author's synthesis

Following the guidelines of Ramayah et al. (2018), HTMT values lower than 0.85 would indicate that discriminant validity has been achieved. With reference to the values in Table 10, it is observed that the values satisfy the guidelines for assessing discriminant validity via the HTMT technique. All three methods of assessing discriminant validity via the Fornell \& Larcker criterion, cross-loadings, and HTMT method indicate that discriminant validity has been established for the constructs in the study. To summarize the above measurement model results for the first stage of the disjoint two-stage approach, it can be concluded that the requirements of internal consistency reliability, convergent validity and discriminant validity has been met. In the next step, the structural model will be assessed.

Table 10 HTMT Criterion

\begin{tabular}{|c|c|c|c|c|c|c|}
\hline & Commitment & Firm Perf & $\begin{array}{c}\text { Info } \\
\text { Sharing }\end{array}$ & Opportunism & Satisfaction & Trust \\
\hline \multicolumn{7}{|l|}{ Commitment } \\
\hline Firm Perf & 0.342 & & & & & \\
\hline Info Sharing & 0.635 & 0.375 & & & & \\
\hline Opportunism & 0.252 & 0.099 & 0.331 & & & \\
\hline
\end{tabular}


HOLISTICA Vol 11, Issue 3, 2020, pp.59-87

$\begin{array}{clllll}\text { Satisfaction } & 0.671 & 0.429 & 0.797 & 0.416 & \\ \text { Trust } & 0.565 & 0.334 & 0.635 & 0.128 & 0.743\end{array}$

Source: Author's synthesis

\subsection{Assessment of Structural Model}

In the second stage of the disjoint two-stage approach, the LVS of the LOC's (Trust, Commitment, Satisfaction and Information Sharing) were used as indicators of the HOC, B2B Relationship Quality. Meanwhile, indicators of the LOC's (Firm Performance and Opportunism) were retained. See Figure 3 below. In the assessment of structural model, the lateral collinearity (predictor-criterion) is of concern because it may lead to incorrect findings and interpretation of the hypothesised relationships. (Ramayah et al. 2018, p. 142). The guidelines for assessing the collinearity in the structural model is similar as in the measurement model that was assessed earlier.

Figure 3 Structural Model

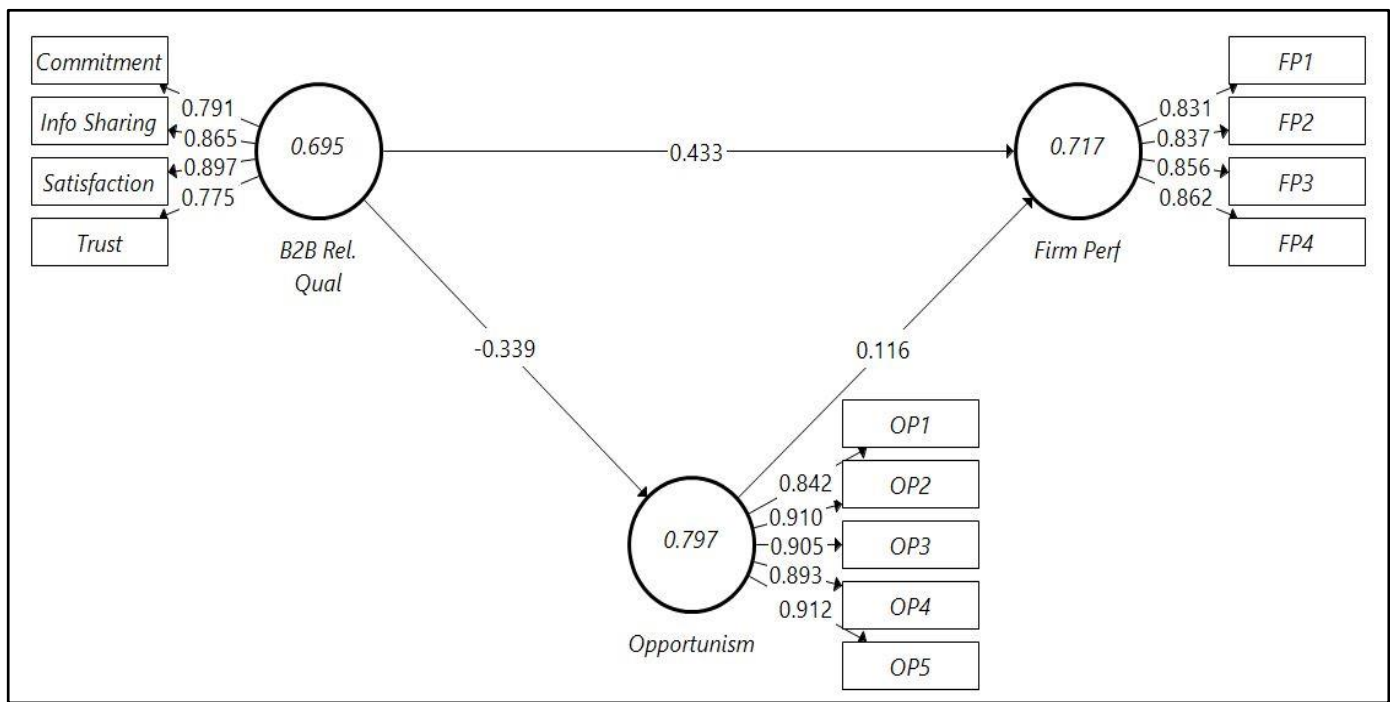

Source: Author's synthesis

In this stage, the loadings of the indicators of B2B Rel Qual has to be assessed. From the LVS, it is observed that the loadings of the indicators of B2B Rel Qual is above the threshold value of 0.7. The AVE and CR values are 0.695 and 0.901 respectively. This implies that B2B Relationship Quality that is now measured with the LVS of the LOC determined in the previous stage has achieved convergent validity at this stage. 
HOLISTICA Vol 11, Issue 3, 2020, pp.59-87

From the Table 11, it can be inferred that the indicators (Trust, Commitment, Satisfaction, Information Sharing) account for $69.5 \%$ of variance of the B2B Relationship quality construct.

Table 11 Loadings, AVE and CR (Structural Model)

\begin{tabular}{llccc}
\hline Construct & Item & Loadings & AVE & CR \\
\hline B2B Relationship Quality & Trust & 0.775 & 0.695 & 0.901 \\
& Commitment & 0.791 & & \\
& Satisfaction & 0.897 & & \\
Information Sharing & 0.865 & & \\
Opportunism & OP1 & 0.842 & 0.797 & 0.952 \\
& OP2 & 0.910 & & \\
OP3 & 0.905 & & \\
Firm Performance & OP4 & 0.893 & & \\
& OP5 & 0.912 & & \\
& FP1 & 0.831 & 0.717 & \\
& FP2 & 0.837 & & \\
& FP3 & 0.856 & & \\
\hline
\end{tabular}

Source: Author's synthesis

Based on Table 12, all inner VIF values for the independent variables (B2B Rel. Qual and Opportunism) are less than the recommended threshold value of VIF $\leq 5.0$. (Hair et al., 2017). This implies that there is no concern of lateral collinearity issue in the structural model.

Table 12 Collinearity in structural model

\begin{tabular}{|c|c|c|c|}
\hline & B2B Rel. Qual & Firm Perf & Opportunism \\
\hline B2B Rel. Qual & & 1.130 & 1.000 \\
\hline \multicolumn{4}{|l|}{ Firm Perf } \\
\hline Opportunism & & 1.130 & \\
\hline
\end{tabular}

Source: Author's synthesis

Out of the hypothesised relationships, it can be observed from Table 13 below, that there is a significant relationship between B2B Relationship quality - Opportunism $(\mathrm{H} 1)$ and B2B Relationship quality - Firm Performance $(\mathrm{H} 2)$. Based on the review of literature, four hypotheses were proposed. However, only two out of four of the hypotheses were supported. From Table 13, $\mathrm{H} 1$ and $\mathrm{H} 2$ were found to have t-value $\geq 1.645$, thus significant 
at 0.05 level of significance. However, $\mathrm{H} 3$ was not significant with t-value $\leq 1.645$ at 0.05 level of significance. Furthermore, the predictor variable B2B Relationship Quality ( $\beta=$ $0.039, p<0.01$ ) is negatively related on Opportunism, which explains $11.5 \%$ of variance in Opportunism. Hence, $\mathrm{H} 1$ is supported. The $\mathrm{R}^{2}$ value of 0.115 is above the 0.02 level recommended by Cohen (1988) indicating a weak model.

Meanwhile, predictor B2B Relationship Quality $(\beta=0.433, p<0.01)$ is positively related on Firm Performance. Hence, $\mathrm{H} 2$ is supported. The $\mathrm{R}^{2}$ value of 0.167 is above the 0.13 value as recommended by Cohen (1988) which indicates a moderate model.

Table 13 Analysis of structural model

\begin{tabular}{|c|c|c|c|c|c|c|c|c|}
\hline Hypotheses & Relationship & $\begin{array}{l}\text { Std } \\
\text { Beta }\end{array}$ & $\begin{array}{l}\text { Std } \\
\text { Error }\end{array}$ & $\begin{array}{c}\mathrm{t}- \\
\text { value }\end{array}$ & Decision & $\mathbf{R}^{2}$ & $f^{2}$ & $Q^{2}$ \\
\hline $\mathrm{H} 1$ & $\begin{array}{c}\text { B2B Rel. } \\
\text { Qual -> } \\
\text { Opportunism }\end{array}$ & -0.339 & 0.106 & 3.2 & Supported & 0.115 & 0.130 & 0.075 \\
\hline $\mathrm{H} 2$ & $\begin{array}{c}\text { B2B Rel. } \\
\text { Qual -> Firm } \\
\text { Perf }\end{array}$ & 0.433 & 0.091 & 4.74 & Supported & 0.167 & 0.200 & 0.098 \\
\hline H3 & $\begin{array}{l}\text { Opportunism } \\
\text {-> Firm Perf }\end{array}$ & 0.116 & 0.125 & 0.927 & $\begin{array}{c}\text { Not } \\
\text { supported }\end{array}$ & & 0.014 & \\
\hline
\end{tabular}

Source: Author's synthesis

From the results above, it can be observed that B2B Relationship quality has a weak effect in predicting the $\mathrm{R}^{2}$ for Opportunism. Subsequently, B2B Relationship quality has a moderate effect in predicting the $\mathrm{R}^{2}$ value for Firm Performance. According to Hair et al. (2017), any value of $Q^{2}$ above 0 indicates that the model has a predictive relevance for the endogenous construct. In this case, there is predictive relevance for both firm performance and opportunism. $\mathrm{Q}^{2}$ values of B2B Relationship quality is larger than zero, indicating that the model has predictive relevance for Firm Performance.

\section{Discussion}

From the results of the analysis, only 2 out of the 4 hypotheses were supported $(\mathrm{H} 1-\mathrm{H} 2$ supported). The results of the study found support that the quality of relationship consisting of trust, commitment, satisfaction, and information sharing between businesses has the ability to impede opportunism ( $\mathrm{H} 1$ supported). From the results of $\mathrm{H} 1$, it can be implied that there is a lower tendency for firms to engage in opportunistic behaviour as if a good business relationship is shared. Ford (1980) suggested that businesses are unwilling to face uncertainty and risks associated with new partners after a good relationship is developed. In other words, opportunistic behaviour has the potential to erode the climate of trust that is shared between businesses in an exchange. A high-quality relationship however is able to inhibit such behaviour as partners are more 


\section{HOLISTICA Vol 11, Issue 3, 2020, pp.59-87}

aligned with their interests and goals (Ali \& Larimo, 2016). Hawkins, Wittmann and Beyerlein (2008) suggested that when firms develop a reputation for behaving opportunistically, the firm may face complications in dealing with other firms who may prefer a cooperative relationship. This would also lead to situations where opportunistic firms have a smaller network of suppliers and customers.

The findings for $\mathrm{H} 2$ sheds new light on how $\mathrm{B} 2 \mathrm{~B}$ relationship quality can lead to better firm performance and is in line with the findings of Huntley (2006) and Ural (2009) and Wang and Yang (2013). A high-quality business relationship that is shared between partners is able to foster a climate of exchange with high levels of trust, commitment, satisfaction and information exchange. The good relationship that is shared will lead to positive economic outcomes and more business opportunities (Niazi \& Hassan, 2016). This is especially the case in the context of businesses in Asia where relationships take precedence over other matters (Xue et al., 2018). Businesses do not often consider alternative sources or changing partners due to the risks and uncertainty that are associated (Ford, 1980). As trust and relations are built over time, there is a tendency for businesses to stick to partners whom they share a good relationship with. This would then lead to a reciprocal effect that leads to a continuous and harmonious business transaction (Kim, Ko \& James, 2011).

$\mathrm{H} 3$ is not supported because the path coefficient was insignificant. Further to that, the correlation was positive instead of negative. This contradicts the findings of past research by Wang and Yang (2013). One plausible explanation is that opportunism is not an antecedent to firm performance. Firm performance as suggested by Kaplan and Norton (1996) can be measured via the financial performance, customer perspectives, learning \& growth and internal processes. In other words, the firm performance is more dependent on the customer perspectives in which is evident from the results of $\mathrm{H} 2$ whereby the quality of relationship shared with business partners is able to predict firm performance.

\subsection{Implications}

TCE and SET are prominent theories that are important and still widely studied to date. An evolution on the use of hybrid governance mechanisms can be observed over time whereby formal contractual mechanisms that were once prominent in governing exchange relationships are now being employed alongside relational mechanisms to promote goal congruence and inhibit opportunistic behaviour between partners. A key contribution to SET is that there exists a social transaction in an economic relationship. The strength of the relationship may be weak at the beginning but as it develops, partners engage in more socio-economic exchanges that lead to positive outcomes. Hence, it is important in an exchange relation with businesses to foster and develop a good relationship rather than behaving opportunistically for self-interests even if the conditions are profitable and feasible (John, 1984).

$\mathrm{B} 2 \mathrm{~B}$ relationships are crucial in relationship marketing. This is because business decisions are no longer solely dominated by pricing factors. As businesses are looking towards the long term for more sustainable business relationships, activities that enable a climate of 
trust, commitment, satisfaction and information sharing needs to be developed. A good example that can be drawn is how Toyota manages its relationship with vendors by forming "Toyota Suppliers Club". This activity allows Toyota to build a better relationship by organising regular meetings with their vendors to network and share information that is beneficial for them and their partners. Although formal contractual relations are important at the beginning of business relationships, the true potential beyond can only be realized if a good relationship exists between firms.

\subsection{Limitations and Recommendations for future research}

Findings of the research must be interpreted with caution due to the cross-sectional design of the study. Although Emerson (1976) suggested that studies of relationships has to be longitudinal in nature, the cross-sectional design of the study captures only the view of the respondents pertaining to the $\mathrm{B} 2 \mathrm{~B}$ relationships at a single point in time. On the contrary, Seggie, Griffith and Jap (2013) noted that longitudinal design cannot explain well the causal mechanisms of relationships due to opinions of the respondents that may differ over the course of time However, longitudinal design is recommended for future testing if there is a need to understand how B2B relationship quality can influence firm performance and opportunism along the time dimension. Future studies should be replicated under different contexts as geographical and cultural distances may result in a lack of trust engendered in relationships (Ford, 1980). Another recommendation for future research is to include firm size as a control variable. This is because trust, commitment, satisfaction and other social constructs may be different among large and small firms. Gilboa, Seger-Guttmann and Mimran (2019) implied that smaller firms perceive that larger companies tend to not be concerned about their interests due to lower potential of superior economic return. Despite the limitations above, the findings of the study may provide some informative insights to businesses within the Malaysian context on how B2B relationship quality can lead to better firm performance and inhibit opportunistic behaviour.

\section{References}

Ali, T., \& Larimo, J. (2019). Managing opportunism in international joint ventures: The role of structural and social mechanisms, Scandinavian Journal of Management, 32, no. 2: 86-96.

Allen, P., Bennett, K., \& Heritage, B. (2014). SPSS Statistics Version 22: A practical guide, 3rd Edition. Australia: CENGAGE learning.

Amoako-Gyampah, K., Boakye, K.G., Adaku, E., \& Famiyeh, S. (2019). Supplier relationship management and firm performance in developing economies: A moderated mediation analysis of flexibility capability and ownership structure, International Journal of Production Economics, 208: 160-170.

Appiah-Adu, K., Okpattah, B.K., \& Djokoto, G.J. (2016). Technology transfer, outsourcing, capability and performance: A comparison of foreign and local firms in Ghana, Technology in Society, 47: 31-39.

Bagozzi, R.P., Yi, Y., \& Phillips, L.W. (1991). Assessing construct validity in organisational research, Administrative Science Quarterly, 36, no. 3. 
Barber, J. (2003). Distributor focus: The case for planning: Distributor \& manufacturer views, New Equipment Digest, 68, no. 5: 36a.

Bennett, R., \& Barkensjo, A. (2004). Relationship quality, relationship marketing, and client perceptions of the levels service quality of charitable organisations, International Journal of Service Industry Management, 16, no. 1: 81-106.

Bhattacharya, A., Singh, P.J., \& Nand, A.A. (2015). Antecedents of buyer opportunistic behaviour in outsourcing relationships, International Journal of Production Economics, 166: 258-268.

Bigne, E., \& Blesa, A. (2003). Market orientation, trust and satisfaction in dyadic relationships: a manufacturer retailer analysis, International Journal of Retail \& Distribution Management, 31, no. 11: 574-590.

Blau, P.M. (1964). Exchange and Power in Social Life. New York: Taylor and Francis.

Cavusgil, S.T., Deligonul, S., \& Zhang, C. (2004). Curbing Foreign Distributor Opportunism: An Examination of Trust, Contracts, and the Legal Environment in International Channel Relationships, Journal of International Marketing, 12, no. 2: 7-27.

Chu, W., Gerstner, E., \& Hess, J. (1998). Managing Dissatisfaction How to Decrease Customer Opportunism by Partial Refunds, Journal of Service Research, 1, no. 2: 140-155.

Cropanzano, R., \& Mitchell, M. (2005). Social Exchange Theory: An Interdisciplinary Review, Journal of Management, 31, no. 6: 874-900.

Cohen, J. (1998). Statistical power analysis for the behavioral science (2nd ed.). Hillsdale, NJ: Lawrence Erlbaum Associates.

Coase, R.H. (1937). The Nature of the Firm, Economica, 4, no. 16: 386-405.

Darlington, R.B., \& Hayes, A.F. (2017). Regression Analysis and Linear Models. New York: Guilford Press.

Day, G.S. (1992). Marketing's Contribution to the Strategy Dialogue, Journal of the Academy of Marketing Science, 20, no. 4: 323-329.

Eisenhardt, K.M. (1989). Agency Theory: An assessment and Review, The Academy of Management Review, 14, no. 1: 57-74.

Emerson, R. (1976). Social Exchange Theory, Annual Review of Sociology, 2: 335-362.

Field, A. (2014). Discovering Statistics Using IBM SPSS Statistics. London: SAGE Publications Ltd.

Ford, D. (1980). The Development of Buyer-Supplier Relationships in Industrial Markets, European Journal of Marketing, 14, no. 5/6: 339-353.

Garson, G.D. (2016). Partial Least Squares: Regression and Structural Equation Models. Asheboro: Statistical Publishing Associates.

Geisser, S. (1974). A predictive approach to the random effect model, Biometrika, 62, no. 1: 101107.

Gilboa, S., Seger-Guttmann, T., \& Mimran, O. (2019). The unique role of relationship marketing in small businesses' customer experience, Journal of Retailing and Consumer Services, 51 : 152-164.

Glen, S. (2015). What is non-response bias? Accessed December 17, 2019. http://www.statisticshowto.com/non-response-bias/.

Hair Jr., J.F., Hult, G.T.M., Ringle, C., \& Sarstedt, M. (2017). A primer on partial least squares structural equation modelling (PLS-SEM). Sage Publications.

Hayes, A. (2019). What is a business? Accessed May 20, 2019. https://www.investopedia.com/terms/b/business.asp .

Heide, J., \& John, G. (1992). Do Norms Matter in Marketing Relationships?, Journal of Marketing, 56, no. 2: 32-44. 
Howard, M.C., \& Crayne, M.P. (2019). Persistence: Defining the multidimensional construct and creating a measure, Personality and Individual Differences,139: 77-89.

Huntley, J.K. (2006). Conceptualization and measurement of relationship quality: Linking relationship quality to actual sales and recommendation intention, Industrial Marketing Management, 35, no. 6: 703-714.

Huo, B., Ye, Y., \& Zhao, X. (2015). The impacts of trust and contracts on opportunism in the 3PL industry: The moderating role of demand uncertainty, International Journal of Production Economics, 170: 160-170.

Huo, B., Fu, D., Zhao, X., \& Zhu, J. (2016). Curbing opportunism in logistics outsourcing relationships: The role of relational norms and contract, International Journal of Production Economics, 182: 293-303.

Jack, E.P., Powers, T.L., \& Skinner, L. (2010). Reverse logistics capabilities: Antecedents and cost savings, International Journal of Physical Distribution \& Logistics Management, 40, no. 3 : 228-246.

Jan-Michael, B., Klein, K., \& Wetzels, M. (2012). Hierarchical Latent Variable Models in PLS-SEM: Guidelines for Using Reflective-Formative Type Models, Long Range Planning,45: 359-394.

John, G. (1984). An Empirical Investigation of Some Antecedents of Opportunism in a Marketing Channel, Journal of Marketing Research, 21, no. 3: 278-289.

Joshi, A.W., \& Stump, R.L. (1999). Determinants of commitment and opportunism: Integrating and extending insights from transaction cost analysis and relational exchange theory, Canadian Journal of Administrative Science, 16, no. 4: 334-353.

Kaplan, R., \& Norton, D. (1996). The Balanced Scorecard: Translating Strategy Action. Accessed May 26 ,

https://books.google.com.my/books?id=mRHC5kHXczEC\&printsec=frontcover \&source $=g b$ s_ge_summary_r\&cad=0\#v=onepage \&q\&f=false.

Karyose, H., Astuti, W., \& Ferdiansjah, A. (2017). Customer Loyalty: The Effect of Service Quality, Corporate Image, Customer Relationship Marketing and Customer Satisfaction as Intervening Variable-An Empirical Analysis of Bank Customers in Malang City, Marketing and Branding Research, 4, no.4: 336-347.

Kenton, W., 'What is a Supply Chain?'. Accessed May 2019. https://www.investopedia.com/terms/s/supplychain.asp.

Kim, Y.K., Ko, Y.J., \& James, J. (2011). The impact of relationship quality on attitude toward a sponsor, Journal of Business \& Industrial Marketing,26, no. 8: 566-576.

Kirk, G.S. (1951). Natural Change in Heraclitus, Mind, 60, no. 237.

Law, K.S., Wong, C., \& Mobley, W.H. (1998). Toward a Taxonomy of Multidimensional Constructs, Academy of Management Review, 23, no. 4: 741-755.

Lin, C.J., \& Chen, C. (2008). Determinants of manufacturers' selection of distributors, Supply Chain Management: An International Journal, 13, no. 5: 356-365.

Liu, C., Guo, Y., \& Lee, C.H. (2011). The effects of relationship quality and switching barriers on customer loyalty, International Journal of Information Management, vol. 31, no. 1: 71-79.

Lumineau, F \& Quelin, BV 2011, 'An empirical investigation of interorganisational opportunism and contracting mechanisms', Strategic Organisation, vol. 10, no. 1, pp. 55-84.

Malik, S., Kanhere, S.S., \& Jurdak, R. (2018). ProductChain: Scalable Blockchain Framework to Support Provenance in Supply Chains, Conference: 2018 IEEE 17th International Symposium on Network Computing and Applications (NCA). https://doi.org/10.1109/NCA.2018.8548322. 
HOLISTICA Vol 11, Issue 3, 2020, pp.59-87

Morgan, R.M., \& Hunt, S.D. (1994). The commitment-trust theory of relationship marketing, Journal of Marketing, 58, no. 3: 20-38.

Mudambi, S., \& Aggarwal, R. (2003). Industrial distributors Can they survive in the new economy?, Industrial Marketing Management, 32: 317-325.

Mysen, T., Svensson, G., \& Payan, J.M. (2011). The key role of opportunism in business relationships, Marketing Intelligence \& Planning, 29, no. 4: 436-449.

Nasim, K., \& Iqbal, M.Z. (2019). Linking relationship quality and resourcefulness to group performance, International Journal of Productivity and Performance Management, 68, no. 3: 626-643.

Ng, E. (2012). An Empirical Study on the Success Factors of Supplier-Distributor Relationships, Contemporary Management Research, 8, no. 2: 161-180.

Nguyen, T.M., \& Nguyen, T.D. (2014). The impact of cultural sensitivity and information exchange on relationship quality, Marketing Intelligence \& Planning, 32, no. 7: 754-768.

O'Cass, A., Ngo, L.V., \& Siahtiri, V. (2015). Marketing resource-capability complementarity and firm performance in B2B firms, Journal of Business \& Industrial Marketing, 30, no. 2: 94-107.

Ono, A., \& Kubo, T. (2009). Manufacturers' intention to extend the relationships with distributors', Journal of Business \& Industrial Marketing, 24, no. 5/6: 439-448.

Ou, W., Shih, C., Chen, C., \& Wang, K. (2011). Relationships among customer loyalty programs, service quality, relationship quality and loyalty: An empirical study, Chinese Management Studies, 5, no. 2: 194-206.

Podsakoff, M.P., Mackenzie, S.B., Lee, J.Y., \& Podsakoff, N.P. (2003). Common Method Biases in Behavioral Research: A Critical Review of the Literature and Recommended Remedies, Journal of Applied Psychology, 88, no. 5.

Podsakoff, M.P., \& Organ, D.W. (1986). Self-reports in organisational research: Problems and prospects, Journal of Management, 12, no. 4: 531-544.

Pooe, D., Mafini, C., \& Loury-Okoumba, V.W. (2015). The influence of information sharing, supplier trust and supplier synergy on supplier performance: The case of small and medium enterprises, Journal of Transport and Supply Chain Management, 9, no. 1: a187.

Procter, S., \& Ackroyd, S. (1998). Against Japanization: understanding the reorganisation of British manufacturing, Employee Relations, 20, no. 33: 237.

Ramayah, T., Cheah, J., Chuah, F., Ting, H., \& Memon, M.A. (2018). Partial Least Squares Structural Equation Modeling (PLS-SEM) using SmartPLS 3.0: An updated and Practical Guide to Statistical Analysis, Second Edition. Malaysia: Pearson.

Rauyruen, P., \& Miller, K.E. (2005). Relationship quality as a predictor of B2B customer loyalty, Journal of Business Research, 60: 21-31.

Ringle, C., Sarstedt, M., Detmar, S.W. (2012). A Critical Look at the Use of PLS-SEM in "MIS Quarterly, MIS Quarterly, 36, no. 1.

Ryu, S., Min, S., \& Zushi, N. (2007). The moderating role of trust in manufacturer-supplier relationships, Journal of Business \& Industrial Marketing, 23, no. 1: 48-58.

Sánchez, J.A.L., Vijande, M.L.S., \& Gutiérrez, J.A.T. (2011). The effects of manufacturer's organisational learning on distributor satisfaction and loyalty in industrial markets, Industrial Marketing Management, 40, no. 4: 624-635.

Sarstedt, M., Hair, J.F., Cheah, J. (2019). How to specify, estimate and validate higher-order constructs in PLS-SEM, Australasian Marketing Journal, 27: 197-211.

Saunders, M., Lewis, P., \& Thornhill, A. (2009). Research Methods for Business Students, 5th Edition. Harlow :Prentice Hall. 
Seggie, S.H., Griffith, D.A., \& Jap, S.D. (2013). Passive and Active Opportunism in Interorganisational Exchange, Journal of Marketing, 77: 73-90.

Sekaran, U., \& Bougie, R. (2016). Research Methods for Business: A Skill-Building Approach. United Kingdom: John Wiley and Sons.

Stone, M. (1974). Cross-validation and multinomial prediction, Biometrika, 61, no. 3: 509-515.

Ural, T. (2009). The effects of relationship quality on export performance: A classification of small and medium-sized Turkish exporting firms operating in single export-market ventures, European Journal of Marketing, 43, no. 1/2: 139-168.

Vázquez-Casielles, R., Iglesias, V., \& Varela-Neira, C. (2013). Collaborative manufacturerdistributor relationships: the role of governance, information sharing and creativity, Journal of Business \& Industrial Marketing, 28, no. 8: 620 - 637.

Vázquez-Casielles, R., Iglesias, V., \& Varela-Neira, C. (2017). Manufacturer-distributor relationships: role of relationship-specific investment and dependence types, Journal of Business \& Industrial Marketing, 32, no. 8: 1240-1260.

Vohringer, C. (2014). Changing Business Processes - Why manufacturers do not sell directly to consumers. Accessed May 21, 2019. https://parsionate.com/en/magazine/changingbusiness-processes-why-manufacturers-do-not-sell-directly-to-consumers/.

Wang, X., \& Yang, Z. (2013). Inter-firm opportunism: a meta-analytic review and assessment of its antecedents and effect on performance, Journal of Business \& Industrial Marketing, 28, no. 2: 137-146.

Williamson, O.E. (1973). Markets and Hierarchies: Some Elementary Considerations, The American Economic Review, 63, no. 2: 316-325.

Williamson, O.E. (1979). Transaction-Cost Economics: The Governance of Contractual Relations, Journal of Law and Economics, 22, no. 2: 233-261.

Xue, J., Lu, S., Shi, B., \& Zheng, H. (2018). Trust, guanxi, and cooperation: a study on partner opportunism in Chinese joint-venture manufacturing, Journal of Business \& Industrial Marketing, 33, no. 1: 95-106.

Yam, R., \& Chan, C. (2015). Knowledge sharing, commitment and opportunism in new product development, International Journal of Operations \& Production Management, 35, no. 7: 1056-1074.

Zhang, C., Cavusgil, S.T., \& Roath, A.S. (2003). Manufacturer governance of foreign distributor relationships: do relational norms enhance competitiveness in the export market?, Journal of International Business Studies, 34: 550-566. 